\title{
MEDICĪNAS VĒSTURES MUZEJA PIRMAIS NOLIKUMS 1944. GADĀ (dokumenta publikācija)
}

Skaidrojot Paula Stradiṇa Medicinas vēstures muzeja sākumgaitu, pirmā plašas publikas apskatei pieejamā ekspozīcija literatūrā tiek datêta ar 1945. gadu. Pirmais par to rakstijis J. Stradiṇ̌̌ [1], un šis gads tiek atkārtots visās nākamās publikācijās. Viņš norāda, ka muzeja ekspozīcija noformēta 1945. gada pirmajos mēnešos, kad ar to iepazinušies pirmie apmeklētāji, bet gada nogalē parādījušās pirmās atsauksmes presē [2]. Tas bija grūtais pēckara laiks, kad profesors P. Stradiṇš bija pārlieku aizṇemts ar dažādiem administratĩviem pienākumiem, tālab jādomā, ka muzeja ekspozīijas izveides darbs noteikti ir iesākts un jau līdz zināmai gatavības pakāpei paveikts agrāk, vācu laikā, kad P. Stradina noslodze nebija tik intensīva.

Latvijas Valsts vēstures arhīvā ir saglabājies dokuments, kas datēts ar 1944. gada 21. aprīli un kas liecina par muzeja juridiskā statusa jau agrākiem meklējumiem - Universitātes Saimniecības padomes apstiprinātie noteikumi par muzeja darbību jeb tā pirmais nolikums, kas 5. jūnijā noraksta veidā nosūtīts visu fakultāšu dekāniem [3]. Tā teksts šeit tiek reproducēts un sniedz vismaz da|ēju priekšstatu par sākotnējām iecerēm un darbības veidu.

Muzeja pirmās ekspozīcijas lokalizācija parasti tiek saistìta ar Pirmā pasaules kara laikā celtu baraku sāṇus no slimnīcas galvenā korpusa uz Ventspils ielas pusi (līdz mūsu dienām nav saglabājusies). Tajā bijušas 23 telpas, kurās 1945. gadā iekārtota ekspozīija. Medicīnas vēstures dekādes laikā 1946. gada februārī Maskavā, runājot par muzeju, P. Stradiṇš par minēto baraku ir izteicies, ka "sākotnēji eksponāti bija savākti citā telpā, bet pagājšvasar mēs aprīkojām šo èku un visu pārvācām tajā" [4]. Viṇš min arī cetras nodạas (pasaules, Latvijas, kara ḳirurgijas vēstures un medicīnas celtniecības), kas atbilst 1944. gada noteikumiem, kuras papildinātas ar piekto - krievu medicīnas vēstures nodalu. Tātad 1944. gada noteikumi radušies, muzejam lokalizējoties citviet slimnīcā.

Diemžēê arhīvā nav saglabājušies (nav uzieti, nav apzināti) Medicīnas fakultātes tā laika sēžu protokoli, bet starp citiem dokumentiem (Universitātes padomes un dekānu padomes sēžu protokoli, rektora pavēles u.tml.) norādes par muzeja reālu eksistenci un darbību atrast pagaidām nav izdevies. Arī meklējumi 
periodikā par iespējamu muzeja darbības sākumu jau 1944. gadā pagaidām ir izrādījušies nesekmīgi, jo gaidāmās frontes maiṇas priekšvakarā diez vai šādai jaunveides informācijai tiktu pievērsta uzmanība. Savukārt, aplūkojot situāciju 1944. gadā, uzmanību piesaista gatavošanās Medicīnas fakultātes 25 gadu jubilejai rudenī, kas gan nenotika un nevarēja notikt sakarā ar tiešo karadarbību. Fakultātes sēdē 1944. gada 26. februārī P. Stradiṇš tika referējis par Latvijas medicīnas vēstures izpētes uzdevumiem, atzīmējot, ka sakarā ar jubileju fakultāte ir nolēmusi apkopot savu vēsturi, bet Medicīnas vēstures muzeja arhīvā savācami visi par to nepieciešamie materiāli [5]. Tātad fakultātes jubileja varēja kalpot arī par stimulu muzeja oficiālai noformēšanai.

Vēl tālāk atskatoties, klūst redzams, ka jau 1940. gada 20. maijā P. Stradiṇš lūdzis no Kultūras fonda 2 tūkst. latu Medicīnas vēstures muzeja ierīkošanai un saṇēmis fakultātes atbalstu [6], taču paliek neizzināts, vai sakarā ar valsts varas maiṇu viņ̌̌ šo naudu ir sañēmis. Savukārt Medicīnas vēstures muzeja otra nozīmīgākā da|a, kas tā sastāvā tika iek|auta 1950. gada 8. martā, - profesora Jāña Maizītes izveidotais Farmācijas vēstures muzejs - ar Ķīmijas fakultātes lēmumu oficiāli tika atvērts jau 1939. gada 10. novembrī un fakultātes palīginstitūtu sastāvā ietverts 1940. gada 8. maijā [7].

Medicīnas vēstures muzejs tika izveidots kā Medicīnas fakultātei pak|auta iestāde un, kā profesora rūpju bērns un lolojums, atradās tās paspārnē, tālab muzeja saglabāšanai varas pārejas posmā visai svarīgi izrādījās tas, ka šajā laikā fakultātes vadība bija uzticēta tieši P. Stradinam: par Medicīnas fakultātes dekāna vietnieku ar rektora rīkojumu vin̄̌ tika iecelts 1944. gada 27. septembrī [8], par dekānu - ar rektora pavēli 1944. gada 5. novembrī [9], un šo pienākumu pildīja līdz 1946. gada 1, septembrim [10]. Lai klūtu par patstāvīgu valsts iestẩi 1957. gada 3. septembrī, Paula Stradina Medicīnas vêstures muzejam vēl nācās iziet garāku līkloču celu, bet tā juridiskais sākums tomêr ir datējams ar 1944. gada 21. aprīli.

\section{Vēres}

1. Страдынь Я. П. Становление Музея истории медицины профессора П. И. Страдыня // Из истории медицины. - Р., 1960. - Т. 3. - С. 139-153.

2. Osis R. Cilvēce cin̄ã pret slimỉbām: Vērojumi prof. P. Stradiṇa medicīnas vēstures muzejā // Cīna, 1945, 4. dec.

3. LVVA, 7427. f., 7. арr., 68. 1., 38., 39. Ip.

4. Страдынь П. И. Избранные труды. - Р., 1965. - Т. 3. - С. 546.

5. Turpat, 343. Ipp.

6. LVVA, 7427. f., 6. apr., 409. 1., 61. Ip.

7. Turpat, 205. 1., 1., 2. Ip.

8. Turpat, 7. apr., 3. I., 45. Ip.

9. LU arhīvs, 10. apr., 26. 1., 1. Ip.

10. Turpat, LVU rektora pavēle $115 / 415$ 1946. g. 13. aug. 


\section{Noteikumi par Universitātes Medicīnas vēstures muzeju}

1. Medicīnas vēstures muzejs ir Universitātes Medicīnas fakultātes iestāde un tā uzdevums ir krāt materiālus par agrākās un tagadējās medicīnas attīstības gaitu, it sevišķi Latvijā, kā arī ar saviem eksponātiem kalpot Medicīnas fakultātes studentu apmācībai.

2. Muzeju vada muzeja pārzinis, kas padots Medicīnas fakultātei. Muzeja pārzini ik gadu ievēl Medicīnas fakultātes padome un apstiprina Universitātes padome.

3. Sava uzdevuma veikšanai muzejs vāc, glabă un izstāda dažādus eksponātus un mācības līdzek|us un ar Medicīnas fakultātes piekrišanu var sarīkot izstādes, ekskursijas un priekšlasijjumus.

4. Muzejam ir tiesība:

a) pieṇemt izstādī̌sanai eksponātus un mācỉbas līdzek|us no iestādēm, biedrībām un privātām personām;

b) ar Medicīnas fakultātes piekrišanu:

1) izdarît eksponātu un mācỉbas līdzek|u apmainu ar iekšzemju un ārzemju muzejiem un kolekcionāriem,

2) deponēt muzeja eksponātus iekšzemes un ārzemju muzejos un izstādēs.

5. Medicīnas vēstures muzejs iedalās šādās galvenās nodalās:

a) vispārējās medicīnas vēstures nodala,

b) Latvijas medicīnas vēstures noda|a,

c) kara ḳirurgijas vēstures nodaja,

d) dziedniecības iestāžu izbūves un iekārtas nodala,

e) arhīvs.

6. Muzeja materiāli sastāv no eksponātiem, gleznâm, zīmẹjumiem, mulāžām, aparātiem, preparātiem, grāmatầm, tabulām, kartēm, diagrammām u.c.

7. Medicīnas vēstures muzejs var izsniegt citām fakultâtềm lietošanā bez atlīizības uz laiku no 1 līdz 3 mēnešiem dažădus eksponātus, aparātus un grāmatas, kas nav pārāk komplicēti un kas pārvadājot un demonstrējot nebojājas.

8. Muzeja arhīvā tiek uzkrāti:

a) visi materiāli par Universitātes Medicīnas fakultātes vēsturi,

b) visi Medicīnas fakultātes mācības spēku darbi, kā arī visi darbi, kas veikti Medicīnas fakultātes institūtos un klīnikās,

c) visu Latvijā iznākušo medicīnisko rakstu novilkumi,

d) visa ârzemju literatūra, kas attiecas uz medicīnas vēsturi Latvijā,

e) medicīniskas grāmatas, kam ir vēsturiska nozīme.

9. Muzeja uzturēšanas izdevumi sedzami no Universitātes kopējā budžetã paredzētiem līdzekliem.

10. Mãcības gada beigās muzeja pārzinis iesniedz Medicīnas fakultātes dekānam darbības gada pārskatu. 
11. Muzeja pārzinis izstrādā un iesniedz caur Medicīnas fakultāti Universitātes padomei apstiprināšanai noteikumus par muzeja apmeklēšanu, par eksponātu izsniegšanu un par muzeja darbvedỉbu (inventāru, dāvinājumu, kases grāmatu).

12. Muzejam ir savs zīmogs, kura lietošanas kārtỉbu nosaka fakultāte.

13. Pie muzeja pastāv vērtību pirkšanas komisija, sastāvoša no muzeja pārziña kā priekšsēdētāja un 2 locekliem, kurus ievēl fakultāte. Komisijas izlemšanai nododami jautājumi par priekšmetu iegādi, kuru vērtỉba pārsniedz RM 100,-. Komisijas atzinumu pirkšanas lietās apstiprina Saimniecības padome.

14. Par sabojātiem vai nozaudētiem muzeja priekšmetiem no vainīgajām iestādēm vai personām iekasējamas attiecīgas summas, kas iemaksājamas Universitātes kasē. Priekšmetu bojājumu vērtību nosaka 13. punktā minētā vêrtību pirkšanas komisija, bet sabojāto vai nozaudēto priekšmetu izslēgšanu no inventāra grāmatâm un šo priekšmetu vērtỉbu apstiprina Saimniecỉbas padome.

15. Muzejam ir tiesỉba muzeja uzplaukšanas veicināšanai krāt speciālus līdzeklus, kuros ieskaitāmi ziedojumi, pabalsti un novēēejumi, kā arī ienākumi no sarîkotầm izstādēm, priekšlasījumiem un ekskursijām, izdotiem rakstiem, ienākumi no pārdotiem muzeja eksponātu fotoattēliem, karšu un diagrammu kopijām un no pārdotiem dažãdiem izstrādājumiem, atskaitot izdevumus, kas šìm vajadzībām segti no budžetā atvēlētām summām. Par speciālo līdzeklu apgrozījumiem muzeja pārzinis ik gadu sastāda speciālo līdzeklu budžeta projektu un iesniedz to Saimniecíbas padomei.

16. Muzeja speciālie līdzekli, apstiprinātā spec. līdzek|u budžeta robežās, izlietojami šādām vajadzībām ar vêttỉbu komisijas katrreizēju piekrišanu: priekšlasījumiem, ekskursiju un mācības līdzeklu izstāžu sarikošanai, eksponātu jauniegādei, muzeja telpu iekārtošanai sakarā ar dažādiem nepieciešamiem jaunievedumiem, rakstu un attēlu izdošanai, komandējumiem, papildu darbinieku atalgojumiem un dažādu mēginājumu izvešanai, kas saisțti ar muzeja darbību.

17. Muzeja speciālo līdzekłu summas glabājas Finansu kasē Universitātes kopējā speciālo līdzeklu rēkinā, un Saimniecỉbas padome par šiem speciālo līdzeklu apgrozijumiem ved savās grāmatās atsevišķu kontu.

LVVA, 7427. f., 7. apr., 68. 1., 39. lp.

The First Statute of the Museum of History of Medicine in 1944: Publication of the Document (Summary)

Publication of the first statutes about the University's Museum of History of Medicine confirmed by the University's economical council on April 21, 1944. Introduction and comments by A. Vîksna.

Arnis Vīksna, Dr. med. h.c., profesors

LU Medicīnas fakultāte

Raina bulv. 19, Rìga, LV 1586 Latvija 